\title{
Rekontruksi Tazkiya al-Nafs Menurut Abu Hasan al-Nadwi
}

\author{
Mulyadi Ibrahim \\ mulya 77@yahoo.com \\ Institut Agama Islam Langsa
}

\begin{abstract}
This article raises the issue of tazkiyah al-nafs or known as the method of cleansing the soul as one of the ways to shape one's morality through the study of a 20th-century contemporary scholar, Abu Hasan al-Nadwi. This article is a literature review and figure where the data is taken from the study document. As a result of this study that Abu Hasan al-Nadwi embed the term Tazkiyah al-Nafs as figh al-Batin or ihsan. While Tazkiyah's typology, according to al-Nadwi, combines the practice of al-Haiat (figh al-Dhahir) with the inner practice (figh al-Batin) these two practices are interrelated so that they can give birth to someone with noble character. Keyword: Abu Hasan al-Nadwi, reconstruction, Taziytun Nafs.
\end{abstract}

Keyword: Abu Hasan al-Nadwi, Rekontruksi, Taziytun Nafs.

\begin{abstract}
Artikel ini mengangakat kembali issue tazkiyah al-Nafs atau dikenal dengan metode pembersihan jiwa sebagai salah satu cara untuk membentuk akhlak karimah seseorang melalui kajian seorang ulama kontemporer abad ke 20 yaitu Abu Hasan al-Nadwi. artikel ini merupakan kajian kepustakaan dan ketokohan dimana data diambil dari studi dokumen. Sebagai hasil dari studi ini bahwa Abu Hasan al-Nadwi menyematkan istilah Tazkiyah al-Nafs sebagai fiqh al-Batin atau ihsan. Sedangkan tipologi Tazkiyah menurut al-Nadwi yaitu menggabungkan amalan al-Haiat (figh al-Dhahir) dengan amalan batiniah (fiqh al-Batin) kedua amalan ini saling berkaitan sehingga mampu melahirkan seseorang berakhlak yang mulia.
\end{abstract}

Kata Kunci: Abu Hasan al-Nadwi, Rekontruksi, Taziytun Nafs.

\section{PENDAHULUAN}

Studi ini mengupas tentang konsep tazkiyah al-Nafs menurut Abu Hasan alNadwi. Kajian ini berfokus pada bagaimana konsep tazkiyah al-Nafs perspektif Abu Hasan al-Nadwi dan relevansinya terhadap pendidikan akhlak di era kontemporer. Konsep atau gagasan (view) tazkiyah al-Nafs Abu Hasan al-Nadwi tidak hanya sebagai konsep mistisme saja, melainkan teraktualisasi dalam kehidupan. Salah satu unsur penting penerapan tazkiyah al-nafs menurutnya harus mengacu pada konsep amaliyah (fiqh al-Dhahir) dan amaliah batiniyah (fiqh albatin) hal ini yang perlu dikoneksikan pada proses pendidikan. Abu Hasan

Jurnal At-Tafkir: Volume 13 Nomor 1 Tahun 2020

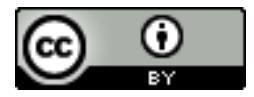

This work is licensed under a Creative Commons Attribution 4.0 International License 
berpendapat bahwa pendidikan harus merujuk pada akidah dan risalah dakwah atau harus memilki nilai-nilai keagamaan dan nilai-nilai moral. Akidah dan nilai moral yang dimaksud merupakan bentuk internalisasi konsep amaliyah (figh alDhahir) dan amaliyah batin (figh al-Batin) atau sifat, karena keduanya merupakan bentuk hubungan vertikal dan horizontal dan hubungan antara diri seseorang dengan manusia dan Allah sekaligus.

Konsep yang disampaikan al-Nadwi tidak hanya pada tataran teoritis, melainkan pada aspek praktis. Dengan demikian, konsep tazkiyah al-Nawi diharapkan mampu terkoneksikan dengan pendidikan dengan harapan mampu membentuk dan membina peserta didik berakhlak karimah. Menurut Abu Hasan krisis moral terjadi karena krisis iman dan krisis akhlak hal ini bisa menjadi bencana besar dalam keberlangsungan kehidupan ummat manusia (Abul Hasan al-Nadwi, 1987) oleh karena demikian pada diri manusia perlu pembersihan jiwa dalam mengobati krisis mentalitas yang sedang berlangsung. Krisis moral tidak hanya terjadi di masyarakat awam, akan tetapi terjadi di semua kalangan dan profesi, tak terkecuali di dunia pendidikanpun merasakan bencana ini sebagaimana digambarkan oleh Azyumardi Azra menyebutkan salah satu akar masalah adalah sekolah dan lingkungannya tidak lagi merupakan tempat peserta didik melatih diri untuk berbuat sesuatu berdasarkan nilai-nilai moral dan akhlak (Azyumardi Azra, 2001). Sekolah cenderung tidak memperdulikan terhadap nilai moral yang dipraktekkan peserta didik.

Sejauh ini dilihat dari segi ketokohan Abu Hasan al-Nadwi dalam perkembangan ilmu pengetahuan era modern sudah banyak diakui oleh para ulama-ulama abad modern, mereka menjadikan gagasan dan pemikiran Abu Hasan sebagai objek penelitian dan dijadikan rujukan dalam menulis karya ilmiah dalam berbagai disiplin ilmu keagamaan khususnya pemikiran Islam.

Syeh Yusuf Qardhawi salah seorang ulama yang mengagumi dan respek terhadap Abu Hasan al-Nadwi baik pemikiran, sikap ilmiah yang sangat konsisten menentang pemikiran barat, maupun sifat dan tingkah lakunya yang zuhud dan tasamuh. Kekaguman beliau melahirkan sebuah karya yang Jurnal At-Tafkir: Volume 13 Nomor 1 Tahun 2020

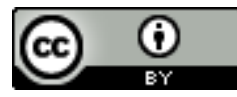

This work is licensed under a Creative Commons Attribution 4.0 International License 
menggambarkan sirah dan pemikiran Abu Hasan al-Nadwi melalui sebuah buku yang berjudul; al-Syaikh Abu Hasan kama 'araftuhu (Yusuf Qardhawi, 2001).

Abdul Mun'im Ustman Ahmad mengkaji pemikiran Abu Hasan al-Nadwi sebagai disertasi berjudul "Abu Hasan al-Nadwi wa fikratuhu al-Tarbawi" (Abu Hasan al-Nadwi dan gagasannya terhadap pendidikan). Fokus penelitian ini mengarah pada konsep pendidikan Abu Hasan al-Nadwi, corak pemikirannya dan mamfaatnya dalam dunia pendidikan Islam (Abdul Mun'in Ustman, 2010). Selanjutnya Mada Wijaya mengupas tentang pemikiran pendidikan al-Nadwi dalam kitab al-Shira' Baina al-Fikrah al-Islamiyyah wal Fikrah al-Gharbiyyah. Artikel ini fokus pada kritik terhadap pendidikan Islam yang sudah terkontaminasi dengan sistem Barat, dalam hal ini al-Nadwi juga menentang sekularisasi yang dikembangkan Barat. al-Nadwi lebih memperjuangkan pendidikan yang mempunyai ruh keislaman yang kuat (Mada Wijaya, 2006).

Selanjutnya Sorimonang menulis artikel tentang Recontruction of Western Civilazation Veiewed by Sayyid Abu al-Hasan Ali al-hasani al-Nadwi, artikel ini fokus pada konsep teologi yang dibangun al-Nadwi (Sori Monang, 2018), Azhari Setiwan munulis ertikel berjudul Syed Abul Hasan Ali Hasani an-Nadwi Tentang Keruntuhan Peradaban, Pandangan Hidup, dan Pendidikan Islam. (Azhari Setiawan, 2017), M. Abduh Al-Mannar dan kawan-kawan menulis tentang Abu Hasan berjudul konsep pendidikan Islam al-Nadwi dalam menangkal liberarisasi (M. Abduh al-Mannar, 2018).

Dilihat dari kajian terdahulu diatas menunjukkan bahwa belum ada kajian yang membahas secara sepesifik terhadap konsep tazkiyah al-nafs yang digagas oleh Abu Hasan, oleh karena itu konsep tazkiyah Nafs Abu Hasan al-Nadwi perlu ditelaah kembali dan sangat sesuai jika dikaitkan dengan realitas sekarang ini yang sedang dilanda penyakit kemorosaotan akhlak. Adapun tujuan kajian ini adalah untuk mengetahui dan memahami konsep rekontruksi tazkiyah al-Nafs menurut Abu Hasan al-Nadwi.

Jurnal At-Tafkir: Volume 13 Nomor 1 Tahun 2020

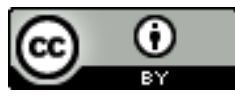

This work is licensed under a Creative Commons Attribution 4.0 International License 


\section{METODE PENELITIAN}

Judul penelitian ini adalah tazkiyah al-Nafs perspektif Abu Hasan al-Nadwi, dengan demikian, data yang digunakan dalam penulisan artikel ini merupakan karya Abu Hasan al-Nadwi yang berkaitan dengan tazkiyah al-Nafs. oleh karena data yang digunakan dalam penelitian ini bersumber dari buku, maka penelitian ini termasuk jenis penelitian kepustakaan (library research). Seluruh data penelitian merujuk pada literatur yang berkaitan dengan objek penelitian, dalam hal ini tazkiyah al-Nafs perspektif Abu Hasan An-Nadwi.

Dilihat dari subjek yang dijadikan fokus penelitian ini adalah seorang tokoh dalam pemikiran Islam, maka penelitian ini juga termasuk studi tokoh. Penelitian studi tokoh biasanya persoalan utama yang ditentukan adalah gagasan-gagasan yang akan digali, kemudian baru ditentukan ketokohnya agar sipeneliti tidak terjebak dalam manipulasi data ketokohan. Melihat dari hal tersebut dianggap relevan kajian ini termasuk dalam studi tokoh, karena penulis awalnya menentapkan gagasan-gagasan kemudian ditentukan tokohnya.

Sumber data primer penelitian ini adalah karya Abu Hasan al-Nadwi yang berkaitan langsung dengan konsep tazkiyah al-Nafs yaitu: Al-'Akidah wa al-I'badah wa al-Suluk fi Zau'i al-Kitab wa al-Sunnah wa al-Sirah Nabawiyah, Rabbāniyah Lā Ruhbāniyah,dan kitab al-Arkan al-Arba'. Sedangkan data skunder dalam penelitian ini adalah buku-buku atau makalah ilmiyah lainnya baik berupa jurnal atau lainnya yang memberi penjelasan ataupun petunjuk tentang biografi Abu Hasan al-Nadwi dan pemikiran tentang tentang konsep tazkiyah al-Nafs.

\section{Biografi dan Perjalanan Ilmiah Abu Hasan al-Nadwi}

Abu Hasan al-Nadwi dilahirkan di desa Takia Kala, Madariyah, Rae Berily, negara bagian Uttar Pardesh (Wilayah Utara) India pada tanggal 23 November 1914 M. bertepatan dengan tanggal 6 Muharram 1333 H. Nama lengkap beliau adalah 'Ali Abu al-Hasan ibn 'Abdul Hay ibn Fakhruddin al-Hasani. Nasabnya terhenti pada Abdullah al-Asytari ibn Muhammad Zî al-Nafs al-Zaiîyah ibn

Jurnal At-Tafkir: Volume 13 Nomor 1 Tahun 2020

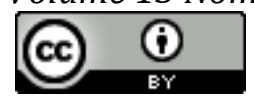

This work is licensed under a Creative Commons Attribution 4.0 International License 
Abdullah al-Mahadh ibn al-Hasan (al-Mutsanna) ibn al-Imam al-Hasan al-Sibt alAkbar ibn Ali bin Abi Thalib Ra. Dilihat dari silsilah beliau maka beliau merupakan keturunan daripada Rasulullah Saw, yang tersambung pada Saidina Hasan bin Ali in Abi Thalib Ra.

Ayahnya bernama Sayyid Abdul Hay bin Sayyid Fakhruddîn al-Hasani lahir pada tanggal 22 Desember 1869 M. (18 Ramadhan 1286 H) merupakan salah seorang tokoh sejarah dan ulama besar di India dengan nama laqab "Ibn Khalkan al-Hind" sekaligus seorang pengarang besar di India. Adapun ibunya adalah Sayyidah Khairun Nisa' merupakan muslimat yang taat, penghafal al-Qur'an seorang muslimah yang cerdas dan seorang penulis dan penyair yang banyak dikagumi para muslimat khususnya di India (Muhammad Ijtiba' al-Nadwi 2001).

Adapun kakak laki-laki bernama Dr. Abdul Ali al-Hasani merupakan salah seorang pemimpin Lembaga Nadwatul Ulama dan juga seorang ulama yang moderat memegang teguh pada ajaran Allah Ta'ala dan Rasul-Nya. Berbekal pengetahuan yang sangat luas Abdul Ali menjadi mandat terhadap keberlangsungan pendidikan dan pengawasan Abu Hasan semasa kecilnya sepeninggalan ayahnya dan berhasil mendidik Abu Hasan sehingga menjadi ilmuan dan ulama besar hingga dikenal seluruh dunia, sedangkan kakak perempuannya bernama Ummah al-'Aziz lahir 1906 M, (1324 H), merupakan 'abìdah (gemar beribadah) juga seorang pengarang kitab. Abū Hasan juga mempunyai seorang adik perempuan bernama Ummatullah Tasnīm yang dikenal dengan Aisyah, merupakan seorang sastrawan wanita, pengarang kitab qishas al-Anbiyā ditulis dengan bahasa Urdu. Adapun juga seorang pengarang kitab dan penterjemah (Yusuf Qardhawi 2001).

Al-Nadwi wafat ketika sedang membaca al-Qur'an, menurut keterangan yang didapat al-Nadwi membaca surat al-Kahfi dan surat Yasin. al-Nadwi wafat karena serangan jantung pada hari Jum'at 23 Ramadhan 1420 H/31 Desember 1999 M, di Takiyah Raybrely sebelum waktu shalat jum'at (Abdul -Mun'īn Usman 2010), maka beliau genap usianya 85 tahun. Berita kepergian beliau langsung menyebar ke berbagai belahan dunia melalui media khususnya media cetak, Jurnal At-Tafkir: Volume 13 Nomor 1 Tahun 2020

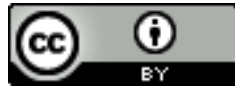

This work is licensed under a Creative Commons Attribution 4.0 International License 
ribuan orang ikut melayat dan menshalatkan serta mengantar jenazah beliau ke pemakaman. Hal serupa dilaksanakan di Masjidil Haram Makkah dan Masjid Nabawi Madinah melaksanakan shalat ghaib setelah shalat Isya pada hari Senin malam ke 27 Ramadhan 1420 H (Al-Raid', 2000).

\section{Pendidikan Abu Hasan al-Nadwi}

Imam al-Nadwi semasa kecil di asuh dan didik oleh ayah, ibu dan kakak laki-lakinya. al-Nadwi banyak belajar secara informal kepada ayah, ibu dan kakaknya di rumahnya. pendidikan awal yang didapatkan adalah belajar huruf ijaiyah kemudian belajar membaca kitab ringan dalam bahasa Urdu, bahasa Farsi dan bahasa Arab yang dikarang oleh ayahnya, diantaranya: (Ta'lìmul Islam dan Nūrul Iman) dan beliau juga belajar Khat (cara menulis bahasa Arab) dalam hal ini ayahnya langsung yang menjadi guru sampai selanjutnya hingga ayahnya meninggal ketika Abu Hasan berumur 9 Tahun. Selanjutnya pendidikan dan pengawasan di lanjutkan oleh ibu dan kakak laki-laki yang tertua menjadi pembimbingnya, berkat didikan ibu dan kakaknyanya al-Nadwi mampu menghafal al-Qur'an dan mendalami pendidikan agama dengan mudah dan cepat.

Belum genap umurnya 12 tahun al-Nadwi mulai membiasakan dirinya dengan berbicara dengan bahasa Arab dengan mudah sehingga ia gunakan untuk membaca dan menelaah kitab-kitab Arab. Pada Tahun 1924 M, beliau mendatangi Syeh Khalil ibn Muhammad al-Anshāri al-Yamāni (1386 H) untuk belajar bahasa Arab dan sastra Arab selama tiga tahun sehingga beliau banyak mendapat mamfaat dan pengalaman secara sempurna dalam keilmuan bahasa dan sastra Arab, Sebagaimana dijelaskan oleh Sayed Iqbal Zaheer dalam bukunya A Man of Hope Through a Century of Turmoil sebagai berikut:

Ali Miyan (Abū Hasan) was entrusted for his Arabic language to a private but unpaid tutorship (Indian scholars never change a fee for this service), of Sheikh Khalil Ibn Muhammad. Originally a Yameni and that time professor in Arabic language at the Lucknow University, he was a teacher of his own class. Following a self-designed syllabus he took his students across miles in weeks. Ali Miyan studied several years under this skillful teacher (Sayed Iqbak Zaheer, 2005).

Jurnal At-Tafkir: Volume 13 Nomor 1 Tahun 2020

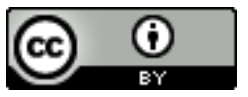

This work is licensed under a Creative Commons Attribution 4.0 International License 
al-Nadwi meneruskan pendidikan pada jenjang kesejarnaan di Lucknow University pada jurusan Bahasa Arab ketika berumur 14 tahun, merupakan murid termuda dalam kelas tersebut dan selesai pada tahun tahun 1927 M. mendapatkan sertifikat dengan prediket mumtaz, lalu al-Nadwi memperdalami ilmu keislamannya lebih lanjut kepada Dr Taqiyyuddin al-Hilāli al-Marākasyi di Nadwatul Ulama pada tahun 1930 M. dilembaga ini al-Nadwi belajar Hadis dan ilmu Hadis (Shahih Bukhari dan Muslim, Sunan Tirmizi, Sunan Abu Daud) dan belajar tafsir (Tafsir Baidhawi) bersama Syeh Haidar Hasan Khan (Muhammad Ijtiba' al-Nadwi, 2001) dan memperdalami ilmu fiqih pada Syeh Syibli (ahli fiqih). al-Nadwi mempelajari bahasa Inggris dan gramatikanya kepada Syeh Khaliluddin dan ustad Muhammad Sami al-Shiddiqi disini Abu Hasan mentakhassus pembelajarannya pada kesusastraan bahasa Inggris.

al-Nadwi banyak berpergian keberbagai daerah menjumpai ulama-ulama besar untuk memdalami ilmu agama hingga mengantarkan dirinya berjumpa dengan seorang tokoh pembaharuan Islam yang moderat Muhammad Iqbal di Lahor (Pakistan). Al-Nadwi berdialog dengannya dan mengungkapkan keinginannya untuk menterjemahkan Qasidah dan Syair Muhammad Iqbal kedalam bahasa Arab dan Muhammad Iqbal sangat terkejut dan saat itu pula beliau bertanya tentang kaidah-kaidah bahasa dan sastra lama dan modrn bahasa Arab. al-Nadwi menetap di Lahore selama 3 bulan dan mendapat pendidikan secara talaqqi bersama Sayyid Ahmad Ali al-Lahori, beliau merupakan dosen Tarbiyah dan Tazkiyah (Muhammad Ijtiba' al-Nadwi, 2001).

\section{Karya-Karya Abu Hasan al-Nadwi}

Menurut Thariq Zubair sebagaimana dikutip oleh al-Ijtba' menjelaskan bahwa setelah dilakukan penelusuran terhadap karya-karya Abu Hasan dalam bahasa Arab dan berhasil dihimpun berjumlah 181 buku termasuk buku-buku kecil atau risalah-risalah dan makalah-makalah yang disampaikan di berbagai pertemuan dan seminar ilmiah di berbagai negara, kemudian diedit dan dijadikan buku (Muhammad Ijtiba', 2001)

Jurnal At-Tafkir: Volume 13 Nomor 1 Tahun 2020

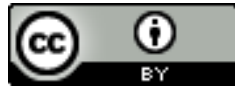

This work is licensed under a Creative Commons Attribution 4.0 International License 
Diantara beberapa kitab mewakili karya-karya al-Nadwi dan berkaitan dengan artikel yang dibahas sebagai berikut: Rabbāniyyah La Ruhbāniyyah (Ketuhanan bukan Kerahiban), Al-'Aqídah wa al-'îbâdah wa al-Sulûk fi dauì al-Kitab wa al-Snnah wa as-Sirah an-Nabawiyyah, Nahwu al-Tarbiyah al-Islämiyyah al-Hurrah, (Menuju pendidikan Islam Yang lebih Bagus), Al-Muslim Fi al-Hind (Sejarah Islam di India), al-Arkān al-Arba'ah (al-Shalah, al-Zakah, al-Saum, al-Haj) fi Dau'i al-Kitab wa al-Sunnah. Ilal Islam Min Jadid, al-Şhirā' Baina al-Fikrah al-Islāmī Wa al-Fikrah alGharbiyyah Fi al-Aktāriq al-Islāmiyyah dan buku Mādza Khasiar al-'Ālam Bi Inhitat alMuslimin.

\section{Faktor-Faktor yang Mempengaruhi Pemikiran Tazkiyah al-Nafs}

Pembentukan pemikiran al-Nadwi dalam melahirkan gagasan tazkiyah alNafs dipengaruhi beberapa faktor diantaranya adalah tokoh-tokoh yang menjadi tauladan dalam kehidupan al-Nadwi sebagaimana diterangkan oleh Yusuf Qardhawi diantarnya Syeh Muhammad Ilyas al-Kandahlawi (1303-1362 H), pendidiri Jamaah Tabligh, lalu Hasan al-Banna (1904-1949 M) pendiri Jamaah Ikhwanul Muslimin, Abdul Qadir ar-Raipuri (1382 H.) dan Muhammad Iqbal (1876-1938 M) Tokoh pembaharuan Islam (Yusuf Qardhawi, 2001).

Sementara kitab atau bacaan yang menjadi pembentukan pemikiran dan berpengaruh dalam kehidupan ilmiahnya dan melahirkan berbagai karya dan gagasannya sebagai berikut: kitab Shanshām al-Islam, karangan: Abdul Razak alHasani. Kitab ini merupakan kitab terjemahan dari kitab Nadham (Futūh al-Syam) karangan al-Wāqidi, Sīrah Rahmatul 'Ālamīn, (Sejarah Nabi), karangan: Muhammad Sulaiman al-Manshūr Puri. Lalu Masdas Hāli (syair dalam bahasa Urdu), karangan: Althāf Husain Hāli. Kitab ini juga merupakan kitab Nazham syair yang menceritakan tentang pemikiran tentang India dan dunia Islam. lalu kitab al-Fāruq (sejarah tentang Uman bin Khatab), karangan: Syibli al-Nu'māni kitab Tafsir surat an-Nur, karangan Ibnu Taimiyah, kitab al-jawāb al-Käfi karangan: Ibnu Kayyim,

Jurnal At-Tafkir: Volume 13 Nomor 1 Tahun 2020

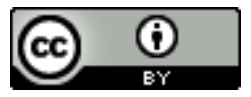

This work is licensed under a Creative Commons Attribution 4.0 International License 
kitab शiyāmul Lail, karangan: Muhammad ibn Nahsr al-Marūzi al-Bahgdadi, Nuzhah al-Khawātir, karangan: Abdul Hay al-Hasani, kitab Mazhab wa 'aqliyāt au Baina al-Dīn wal 'Ākl, karangan: Abdul Bāri al-Nadwi dan kitab Armaghān Ahbāb (sejarah tentang rihlah orang tuanya Abdul hay ke Delhi, ke luar negeri dan perkampuganperkampungan (Yusuf Qardhawi, 2001).

Al-Nadwi lahir dan besar pada abad kedua puluh masa perang dunia kedua dimana negara-negara ketimuran sebagian besar dijajah oleh bangsa Eropa tidak terkecuali negara India pun masih dalam penjajahan kolonial Inggris, oleh karena itu pengaruh peristiwa besar tersebut dirasakan secara nyata oleh beliau dan tidak bisa dielakkan, meskipun al-Nadwi secara nyata menentang penjajahan tersebut khusunya pada bidang politik, keagamaan dan pendidikan. Al-Nadwi melihat pada kenyataanya kekuatan Barat sudah memporak-poranda tatatan sosial ketimuran khususnya dalam hal politik, agama, ekonomi dan pendidikan, oleh karena itu pada setiap kesempatan melalui tulisannya beliau lebih banyak mengkritik dan membangkitkan semangat ummat Islam untuk bangkit dari keterpurukan

Konfilk secara nyata antara Timur dan Barat membuat sistem pendidikan dan kebudayaan India dan ummat Islam pada umumnya hancur dan terkontaminasi dengan kebudayaan Barat memaksa ummat Islam memilih dua jalan yang sangat sulit "antara mempertahankan kehidupan Islamiyah dengan dasar akidah dan iman, dan antara mempersilahkan kehidupan budaya Barat dengan dasar kekuatan dan modern (al-Quwwah wa al-Taqaddum)" hal ini sebagaimana yang telah di rekayasa dan dipraktekkan oleh kerajaan Inggris terhadap negara ketimuran (khususnya India) dengan memperkanalkan Ilmu pengetahuan yang modern dan peraturan-peraturan yang baru dan memperlihatkan temuan-temuan perlengkapan yang modern, industri dan pandangan-pandangan falsafat.( Abū Hasan Nadwi, 1968)

Kondisi ini digambarkan al-Nadwi sebagai kondisi yang sangat memprihatinkan, dua hal yang berkembang saat itu yaitu; masalah kepemimpinan agama (religius leadership) dan madrasah yang menggunakan sistem lama (ancient Jurnal At-Tafkir: Volume 13 Nomor 1 Tahun 2020

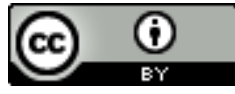

This work is licensed under a Creative Commons Attribution 4.0 International License 
madrasas) atau dengan kata lain "qiyādah al-Diniyyah wa al-Madrasah al-2adīmah". Kelompok Qiyādah al-Dinniyyah dipimpin oleh para ulama dan kelompok al-Qiiyādah al-Madrasah (qiyadah fikriyah) yang di pelopori oleh Sayyid Ahmad Khan (pendiri universitas Aligarh Muslim University) bersama murid-muridnya dan pengikutpengikutnya dari tokoh madrasah modern. Pada saat bersamaan untuk menjembatani antara kelompok ulama-ulama konservatif dan uluma-ulama modern muncul harakah Nadwatul Ulama, harakah ini di pelopori oleh Maulana Muhammad Ali al-Munghiri (1846-1949 M) dan dipimpin oleh Syeh Syibli alNu'mani (1284-1332 H,), harakah yang menaungi Abu Hasan al-Nadwi dalam kiprah kependidikan dan keilmuannya, harakah ini mengusung konsep "al-2adīm al-Shälih wa al-Jadīd al-Näfi'" (konsep klasik itu benar dan konsep modern bermamfaat) atau disebut juga dengan washatiah dalam konsep Nahdhatul Ulama di Indonesia.

Di tengah-tengah kondisi ini lah Abu Hasan tumbuh dan berkembang dan atas pengaruh kondisi sosial politik, agama dan pendidikan beliau ditempa menjadi seorang tokoh dan ilmuan besar dan ulama yang memilki sifat qan'ah dan zuhud yang disegani dunia dengan pikiran-pikiran dan karya beliau yang mungusung kelompok washatiah tanpa bersinggungan dengan kelompok atau ulama lain khususnya dalam gagasan tazkiyah al-Nafs.

\section{HASIL DAN PEMBAHASAN}

\section{Pemahaman Tazkiyah menurut al-Nadwi}

Tazkiyah al-Nafs merupakan kalimat yang berasal dari bahasa Arab yang terdiri dari dua suku kata yaitu tazkiyah dan al-Nafs. Tazkiyah merupakan kalimat mashdar dari zakã yang berarti tumbuh, suci (tathahhur) atau bersih (Ahmad Warson Munawwir, 2002)' dalam bahasa Inggris disebut purify (membersihkan, menyucikan), sedangkan nafs artinya: jiwa atau ruh (soul). Tazkiyah al-Nafs diartikan dengan penyucian diri (the purification of the soul)

Jurnal At-Tafkir: Volume 13 Nomor 1 Tahun 2020

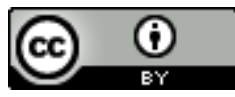

This work is licensed under a Creative Commons Attribution 4.0 International License 
Secara operasional kalimat tazkiyah berkaitan dengan kalimat zakat yang artinya berkah atau menyucikan. Adapun tujuan dari pemberian zakat adalah untuk mendapat keberkahan dari Allah Swt. dan untuk membersihkannya dari sifat kekikiran. Zakat terbentuk dari dua kata benda yang merupakan panduan antara yang dikeluarkan dan perbuatan. Dalam kamus al-Munjid disebutkan bahwa:

$$
\text { الز كاة: ما تقدمه من مالك لتطهره به اي الصدقة, الطهارة: صفوة الشئ }
$$

"Zakat artinya mengeluarkan hartamu untuk membersihkannya atau bersedekah. Zakat juga disebut dengan membersihkan sesuatu" (al-Munjid, 1986), secara harfiah artinya harta yang dikeluarkan untuk zakat dan secara maknawi artinya penyucian.

Kalimat zakā banyak sekali dijumpai dalam al-Qur'an baik dalam bentuk kata kerja maupun mashdar seperti yang terdapat surat al-Mu'minun ayat 4 Allah Swt, berfirman:

$$
\text { والذين هم للز كوة فعلون (4) }
$$

"Dan orang-orang yang membayar zakatnya" (QS. al-Mu'minun, [23] 4).

Ibnu kasir menjelaskan bahwa zakat disini mengandung dua makna yaitu mensucikan diri (jiwa) dan mensucikan harta (Ibnu kasir, 1998). Lawan dari kata tazkiyah adalah tadsiyah yang berarti pengetoran. Makna asli tadsiyah adalah ikhfa' yang berarti menyembunyikan atau menguburkan (Anas Ahmad Karzon, 2016). Dalam ayat yang lain juga disebutkan Allah Swt, berfirman:

$$
\text { قد أفلح من زكها (9) وقد خاب من دسها (10) }
$$

"Sesunguhnya beruntunglah orang-orang yang mensucikan jiwa, dan merugilah orang- orang yang mengotorinya" ( QS. Al-Syam, [10] 11).

Ibnu kasir memberikan keterangan bahwa "beruntunglah bagi orang yang mensucikan jiwanya dengan taat kepada perintah Allah Swt". Qatadah

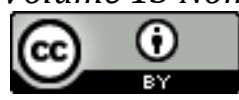

This work is licensed under a Creative Commons Attribution 4.0 International License 
menambahkan " mensucikan dari akhlak yang buruk dan tercela (Ibnu kasir, 1998). Ibnu Taimiah dalam Majmu' fatāwaā sebagaimana dikutip oleh Anas Ahmad Karzon menjelaskan bahwa tazkiyah bermakna menjadikan sesuatu menjadi suci, baik zatnya maupun keyakinan dan bentuk fisiknya. Ibnu Taimiyah mengambil contoh dari pemaknaan ayat al-Qur'an surat al-Najm ayat 32. Allah Swt berfirman: فلا تُز كو أنفسكم (23)" Maka jangalah kamu ( mengatakan) jiwamu suci". Tazkiyah dalam ayat ini bermaksud memberitahu orang lain bahwa jiwanya suci ( Anas Ahmad Karzon, 2016).

Menyikapi terminologi dan Istilah tazkiyah al-Nafs, yang disebutkan diatas, al-Nadwi tidak mendefenisikan secara terperinci, tetapi al-Nadwi lebih melihat dan mengkritisi penggunaan kalimat tasawwuf dan penyebutan serta pemaknaan dan tujuan penggunaannya yang dianggapnya telah melenceng jauh dari pemahaman dan pemaknaan aslinya, dalam hal ini al-Nadwi lebih suka menggunakan kalimat tazkiyah al-Nafs sebagai pengganti dari istilah tasawuf (Abu Hasan al-Nadwi, 1966) dan cenderung mengembalikan permasalahan terminologi atau penamaan terhadap suatu ilmu berujuk kepada al-Qura'an dan Hadis, dengan kata lain al-Nadwi tidak mementingkan terminologi tapi lebih konsen kepada aksiologi.

Lebih lanjut al-Nadwi dalam kritikannya dan menyeru menyeru kepada para ilmuan dan para ahli untuk kembali ke penyebutan tazkiyah al-Nafs, dengan kalimay ihsan atau fiqh batin sebagai istilah yang sudah didapatkan dalam al-Qur'an dan hadis ketimbang menggunakan terminologi 'ajam (istilah bukan dari Islam). Istilah tazkiyah al-Nafs dipandang beliau terminologi yang sangat tepat penyebutannya dalam lingkungan Islam karena pada tazkiyah al-Nafs mempunyai beberapa mamfaat sebagai obat nabi (tibbun Nabi), menghubungkan hati dengan Tuhan, menghubungkan jasad (raga) dengan ruh (jiwa), menghubungkan masyarakat dengan Allah, menghubungkan ulama dengan Rab-nya, menahan hawa nafsu syahwaniah dan fitnah harta dan anak, menahan hawa nafsu hiasan

Jurnal At-Tafkir: Volume 13 Nomor 1 Tahun 2020

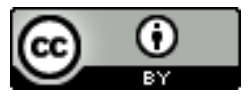

This work is licensed under a Creative Commons Attribution 4.0 International License 
duniawiah dan pada tatatan pemimpin bisa menahan hawa nafsu dan sifat-sifat iblis dan janji-janji paslu dan berlaku tidak adil serta dhalim terhadap masyarakatnya.

Dalam al-Qur'an disebutkan "Dialah yang mengutus kepada kaum yang buta huruf seorang rasul diantara mereka, yang membacakan ayat-ayatNya kepada mereka, menyucikan mereka dan mengajarkan kepada mereka kitab dan hikmah. (QS. al-Jumu'ah [62]: 2)". Kalimat tazkiyah (menyucikan diri) yang ada pada ayat ini menjadi sandaran dalam memaknai tazkiyah, al-Nadwi berkata:

"Jika kita menyesuaikan terminologi Tazkiyah Secara umum merupakan narasi yang sudah terbangun pada abad ke II H, dan bila merujuk kepada al-Qura'n, hadis serta para sahabat dan tabi' tabi'in, kita berharap istilah ini ditemukan dalam al-Qura'n dan hadis dan kami menemukannya dalam alQura'n kalimat ini disebut sebagai bagian dari devisi agama dan urgensinya merupakan urgensi kenabian (nubuwah). Ungkapan tazkiyah disebut sebagai rukun dari rukun yang empat (abadah shalat, zakat, puasa dan menunaikan haji), adapun diutus rasululah Saw, untuk membenarkan dan menyempurnakannya, sebagaimana terdapat pada al-Qur'an (alJumuah [62]: 2) tentang tazkiyah al-Nafs, tahzibnya dan tahallinya dengan sempurna dan menghilangkan sifat-sifat yang tercela" (Abu Hasan, 1966).

Ungkapan al-Nadwi diatas mendiskribsikan bahwa tazkiyah al-Nafs selain sudah ditemukan dalam al-Qur'an dan dipahami sebagai bagian dari devisi agama yang harus dimilki oleh nabi dan diajarkan kepada ummatnya, tazkiyah dipahami sebagai gambaran astrak dari al- Arkān al-Arba'ah (shalat, puasa, zakat dan haji) karena tujuan diutus rasulullah Saw ke muka bumi adalah untuk memperbaiki dan dan mengosongkan hati dari penyakit dan kotoran hati seperti iri, dengki, hasut, takabbur (takalli) lalu mengisi jiwa dengan sifat-sifat terpuji dan menyinari hati dengan perbuatan yang baik atau amal shaleh (tahalli), dan pada akhirnya melahirkan jiwa yang baik dan berakhlak dengan akhlakul karimah.

Tipologi Tazkiyah al-Nafs yang digambarkan al-Nadwi terbagi dua pertama ibadah yang membutuhkan pergerakan atau ibadah yang dapat dirasakan secara dhahir (af'all al-haia'h) atau disebut juga dengan fiqih dhahir

Jurnal At-Tafkir: Volume 13 Nomor 1 Tahun 2020

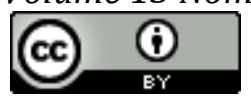

This work is licensed under a Creative Commons Attribution 4.0 International License 
seperti mendirikan shalat, puasa, zakat, menunaikan haji, membaca al-Qura'n, bertasbih, berdoa, berzikir, berdakwah, bermujahadah dan lainnya. Kedua ibadah bathiniyah (kaifiyat bäținiyah), dalam prakteknya ibadah batiniyah mengiringi ibadah haia'h seperti ikhlas bermuhasabah, sabar dan tawakkal, zuhud dan kaya hati, kemulian, dermawan, sopan santun, malu, khusu' dalam melakukan shalat, zuhud dalam bingkai kehidupan dan bersegera mengingat akhirat, rindu berjumpa Allah Ta'ala dan lain-lainnya yang berkaitan dengan ibadah batiniah dan akhlak imaniyah yaitu gambaran syariat yang turun dari jasad kedalam jiwa dan dari ibadah dhahir ke ibadah batin. Konsep ini secara detail membentuk sebuah pemahaman baru yaitu ibadah dhahiriyah disebut dengan fiqh dhahir sebagai syarat utama dalam membentuk tazkiyah dan ibadah yang kedua (ibadah batiniah) disebut dengan fiqh batin sebagai amalan yang mengiringi ibadah dhahiriah (Abu Hasan al-Nadwi, 1966).

Berdasarkan keterangan diatas dapat disimpulkan bahwa menurut alNadwi tazkiyah dinamakan dengan ihsan atau fiqh batin. Tazkiyah merupakan ilmu yang memastikan pelaksanaan tahzibul akhlak, cara seseorang untuk membersihkan diri dari perbuatan tercela (takhalli) akhlak yang terpuji dan mengisi diri dengan amal shaleh (tahalli) dan pada akhirnya akan membentuk akhlak yang terpuji (tajalli) seperti akhlak nabi dengan cara mengikuti sunnah rasul Saw, baik dengan amaliah, sifat batiniyah maupun dengan cara beriman (kaifiat imaniyah).

Adapun model tazkiyah al-nafs al-Nadwi menurut penelusuran peneliti adalah gabungan antara kedua ibadah yaitu ibadah haia'h dan ibadah batiniah, kedua amalan ini dilakukan beriringan sehingga mampu melahirkan tazkiyah dalam jiwa manusia dan pada akhirnya akan melahirkan sikap dan akhlak yang baik pada diri manusia baik akhlak kepada Khalik maupun akhlak kepada makhluk.

Berbeda dengan pendahulunya tipologi yang dibangun seperti al-Ghazali terdapat tiga polarisasi, yaitu al-'adah, al-Muhlikat dan al-Munji'at atau dengan kata lain disebut juga dengan ibadah vertikal (hubungan dengan Allah),

Jurnal At-Tafkir: Volume 13 Nomor 1 Tahun 2020

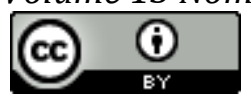

This work is licensed under a Creative Commons Attribution 4.0 International License 
horizontal (hubungan sesama manusia) dan individual ( hubungan manusia dengan dirinya sendiri) (Masyuri, 2012). Lalu Ibnu Taimiyah membuat polarisasi tazkiyah atas tiga hal yaitu; iman dan tauhid, mengikuti sunnah Rasul dan mengerjakan hal-hal yang diwajibkan dan yang disunnahkan (Ibnu Taimiyah, 1994). Berbeda dengan dengan tipologi tazkiyah yang digagas oleh Ibnu Qayyim dimana tazkiyah al-Nafs bisa diperoleh melalui tiga proses yaitu ilm, tazakkur dan riadhah. (Muhammad Habib Fathuddin, Fachrur Razi Amir, 2016).

\section{Fiqh al-Dhahir Sebagai Media Tazkiyah al-Nafs}

Tazkiyah al-Nafs bisa terwujud apabila dilaksanakn ibadah amaliyah alHai'ah atau fiqih bathin secara baik. Dalam hal ibadah al-Nadwi memposisikannya sebagai hal paling penting, Ibadah merupakan tujuan utama penciptaan manusia (Qs, al-Zariyat: 56). Al-qur'an dan hadis sudah banyak menggambarkan bagaimana cara beribadah seseorang kepada Khaliq baik berupa ibadah mahdhah maupun ghairu mahdhah (ibadah-ibadah sunnah) hal ini menunjukkan bahwa ibadah sangat erat kaitannya dengan Tuhan. Ibadah dikerjakan dengan syarat dan rukunnya secara sempurna, sahnya atau tidak sah seseorang beribadah ditentukan oleh syarat dan rukunnya dikerjakan dengan sempurna seperti shalat, puasa, zakat dan haji.

Dalam Islam rukun Islam menjadi pondasi dasar dalam beriman dan beribadah seseorang, kompleksitas keimanan seseorang diukur dari realisasi mengamalkan rukun Islam, ketika seseorang telah mengucapkan syahadah maka rukun Islam yang lain menjadi wajib untuk dikerjakan dengan sempurna sesuai dengan ketentuan yang telah diatur dalam ilmu fiqih dan apabila ditinggalkan berdosa kepada Tuhan. al-Nadwi berpendapat bahwa ibadah dan pilar agama merupakan landasan sistem beragama (Hajur al-Zawiyah Fi Nidhami al-Dini) (Abu Hasan al-Nadwi, 1983) oleh karena itu seseorang yang sudah memeluk agama Islam maka diwajibkan untuk merealisasikan rukun Islam.

Shalat sebagai wasilah penghubung antara manusia dan Tuhan

Jurnal At-Tafkir: Volume 13 Nomor 1 Tahun 2020

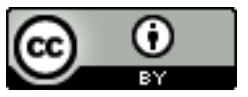

This work is licensed under a Creative Commons Attribution 4.0 International License 
Ibadah shalat merupakan ibadah yang paling utama dalam rukun Islam, shalat merupakan tiang agama yang harus ditegakkan oleh setiap pribadipribadi muslim yang sudah akhir baligh. shalat juga merupakan hal yang paling pertama dihisab di hari akhirat, oleh karena itu shalat harus ditegakkan tanpa ada pengecualian. al-Nadwi mengungkapkan bahwa shalat sebagai pembeda antara orang kafir dengan muslim dan diumpamakan seperti seperti ikan yang membutuhkan air (Abu Hasan al-nadwi, 1983) ini menunjukkan bahwa ibadah shalat adalah ibadah yang sangat penting sehingga al-Nadwi membandingkan dengan orang kafir apabila seorang muslim dalam hidupnya tidak mengerjakan shalat dan mengumpamakan kebutuhan seseorang terhadap shalat sama seperti ikan yang membtuhkan air pada setiap saat, demikian juga manusia membutuhkan Allah Ta'ala disetiap detik dan shalat lah sebagai jawaban dari kebutuhan seorang hamba terhadap Tuhannya.

al-Nadwi menambahkan bahwa shalat bukanlah pakaian besi dan sesuatu yang kaku dan sangat terbatas, akan tetapi shalat bagaikan halaman yang luas yang mampu melatih seseorang dari suatu situasi kesitusi yang lain, dari permulaan menjadi kesempurnaan, dari suatu yang sudah perfek dan tidak membawa dirinya terhadap situasi yang berbahya. Shalat juga mampu memangkas zona dan waktu kepada Tuhan dan tidak ada jarak dan dinding yang menghalangi seseorang untuk berkoneksi kepadaNya dan tidak ada ibadah yang serupa dalam Islam, dengan shalat seseorang bisa mencapai tingkat mukhlis, mujahid, beriman, beilmu dan ma'rifat, mencapai tingkat rabbani, ruhiyah, al-Qarbu (kedekatan). Posisi ini tidak mampu didapatkan hanya melalui kepintaran intelektual saja, akan tetapi bisa dicapai dengan melakukan shalat secara khusyu' dan benar.

Adapun fungsi shalat diantaranya sebagai sarana untuk membangun komunikasi antara seorang hamba dengan Rabnya, hubungan yang berafeliasi kepada pembentukan sifat, sebagai media dalam mewujudkan segala permohonan, sebagai subjek untuk merendahkan diri, terbentuk koneksitas antara Tuhan dan manusia secara berimbang dan masuk akal ( $\left.m a^{\prime} k u l\right)$,sebagai

Jurnal At-Tafkir: Volume 13 Nomor 1 Tahun 2020

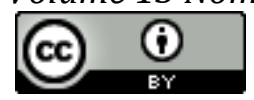

This work is licensed under a Creative Commons Attribution 4.0 International License 
pembentuk pribadi yang lembut, sebagai tempat untuk berlindung, sebagai penyeimbang antara jasad, pikiran dan hati, sebagai nutrisi spritual kejiwaan yang tepat, penentuan jumlah rakaat dan waktunya ditentukan secara ilmiah dan terdapat mamfaatnya. Sebaliknya orang yang meninggalkan shalat akan mendapat ganjaran semasa hidupnya dari Allah seperti, mendatangkan pada dirinya kerusakan, membuat ia frustasi terhadap apa yang telah ia kerjakan, iman akan hilang dalam hati manusia dan orang yang meninggalkan shalat bagaikan domba yang kehilangan pengembalanya sehingga dengan mudah srigala dapat memangsanya (Abu Hasan al-Nadwi, tt).

\section{Zakat, infaq dan sadakah sebagai pembentuk karakter yang lembut}

Zakat dan sedekah menjadi sarana terpenting bagi penyucian jiwa dan sarana untuk meraih ridha Tuhan, banyak ayat-ayat al-Qur'an dan Hadis yang bersifat perintah untuk menunaikannya dan bahkan disebut kafir bagi orang yang mengingkarinya, zakat merupakan hal yang terpenting dalam perekonomian Islam menjadi solusi untuk mengurangi kemiskinan karena zakat merupakan hak orang fakir dan miskin yang wajib dikeluarkan oleh orang yang kaya dan bukan merupakan sumbangan melainkan kewajiban mutlak, disamping itu Islam juga memerintahkan sedekah yang merupakan amal tambahan yang bersifat suka rela.

Menurut para ulama dua hal zakat dan sedekah bisa menjadi penyucian jiwa seseorang yaitu; menjauhkan diri dari ria, bangga diri, dan mengungkinya di depan orang banyak. Selanjutnya menafkahkan harta yang disukai bukan yang tidak disukai dan melakukannya dengan penuh keikhlasan bukan karena kewajiaban yang diperintahkan agama, akan tetapi ia lakukan semata-mata karena mengharap ridha Allah Swt (Anas Ahmad Karzon, 2014).

al-Nadwi mendiskripsikan bahwa zakat berfungsi sebagai hubungan antara Rabun dan hambaNya, sebagai manifestasi sifat rububiyah dan sifat isti'anah (saling tolong menolong) sesama manusia dan hartanya berdampak pada kehidupan masyarakat, situasi faktual yang dibutuhkan manusia untuk tidak menentukan kepemilikan harta bagi manusia tidak berlebihan supaya

Jurnal At-Tafkir: Volume 13 Nomor 1 Tahun 2020

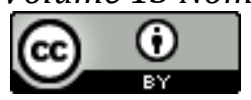

This work is licensed under a Creative Commons Attribution 4.0 International License 
kepemilikan harta seluruhnya dipersembahkan kepada Allah Ta'ala, zakat sebagai ide dasar dalam sistem ekonomi Islam bertujuan untuk menentukan kepemilikan harta secara hakiki kembali kepada Allah Ta'ala, sebagai dorongan untuk berinfak pada jalan Allah Ta'ala dalam membangun peradaban muslim dengan penuh semangat, sebagai kebutuhan terhadap kepastian hukum dan sistem zakat sesuai dengan kebutuhan dan perkembangan zaman (Abu Hasan al-Nadwi, tt)

\section{Puasa sebagai sarana untuk menahan hawa nafsu}

al-Nadwi mendeskripsikan puasa dan kaitannya dengan kejiwaan manusia sebagai berikut, pertama puasa mampu memberikan kekuatan kepada jiwa dan jasad manusia, sekaligus membawa keduanya kepada satu titik keistimewaan (Abu Hasan al-Nadwi, tt) kegiatan yang kedua adalah menahan syahwat jasadiyah. al-Nadwi berkata:

"jika tubuh menguasai kendali hukum, dia akan mengumbar manusia untuk meraup kelezatan syahwat, serta bersenang-senang laksana binatang ternak, lalu jadilah ia di tengah-tengah kemoderenan dan peradabannya dipuncak ilmu pengetahuan dan badanya, bagaikan keledai yang berputar-putar mengelilingi tepung, atau kerbau pembajak sawah yang aktifitasnya hanya berkisar antara tempat makan dan kakus saja, ia tidak mengetahui kecuali itu saja tempat ia bermula dan tempat kembali" (Abu Hasan al-Nadwi, tt).

Manusia sebagaimana digambarkan al-Nadwi pada untaian kaliamat diatas hanya menjadikan hidupnya untuk bekerja dan memenuhi kebutuhan jasadiahnya saja, ia hanya terfokus pada materi semata. Apabila kekuatan jiwa (sulthan roh) melemah atau hilang dan bayangannya mengecil maka kekuatan jasad (sulthan jasad) dapat memerintahkan hasrat manusia untuk mengikuti hawa nafsu, sifat-sifat kebinatangan dan hilang akal sehatnya sehingga ia melakukan sesuatu diatas akal sehatnya dan melawati batas-batas syariat.

Apabila tabiat (sifat) hayawaniyah menguwasai dan mengendalikan kehidupan ia akan mengakuisisi perasaan dan indera manusia maka, perut menjadi poros yang mengelilingi kehidupan manusia ia akan mencabik-cabik

Jurnal At-Tafkir: Volume 13 Nomor 1 Tahun 2020

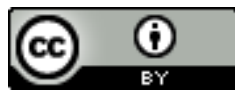

This work is licensed under a Creative Commons Attribution 4.0 International License 
keimanannya, ia akan mengutamakan kesenangan diniawiyah semata dengan mengikuti hawa nafsu ketamakan, oleh karena itu puasa mampu meredam sifatsifat yang tersebut diatas puasa akan berefek kepada perhitungan dan muhasabah diri karena perut lapar manusia akan memikirkan Tuhan ia akan memperhatikan ibadah kepada Rabnya dan perasaanya hidup senang dalam beribadah dan berzikir.

Imam al-Ghazali menjelaskan bahwa diantara makasid puasa adalah berakhlak dengan akhlak Allah Ta'ala dengan mengikuti contoh sifat malaikat dalam hal menahan hawa nafsu karena malaikat pada dasarnya tidak memilki hawa nafsu, selanjutnya manusia derajatnya lebih tinggi daripada binatang karena pada manusia dikaruniai cahaya akal yang mampu menghancurkan syahwatnya dan mampu menyamai derajat malaikat ketika imannya penuh dan sewaktu-watu imannya turun dan bercampur dengan sifat kebinatangan, ketika hawa nafsu dimusnahkan maka derajatnya tinggi setingginya bahkan melebihi dari pada mailakat.(Abu Hasan al-Nadwi, tt).

Anas Ahmad Karzon menjelskan bahwa puasa dapat berperan dalam penyucian jiwa karena puasa mampu melatih jiwa untuk menyempurnakan penghambaan kepada Allah ta'ala, puasa mampu memperkuat motivasi dalam melatih kesabaran, pusa berperan untuk melatih jiwa berjihad melawan hawa nafsu dan terakhir puasa mampu memperkenalkan pada diri manusia kadar keimanannya kepada Allah Swt (Anas Ahmad Karzon, 2014). Adapun tujuan perintah puasa dalam Islam adalah untuk menahan jiwa dari perbuatan maksiat dan menghalanginya dari dominasi hawa nafsu dan syahwat, sedangkan orang yang berpuasa dan tidak meninggalkan perbuatan maksiat, maka puasanya tidak mampu mengubah prilaku dan perbuatannya maka puasanya hanya sebatas melakukan tradisi dan kebiasaan saja, puasanya tidak bermamfaat bagi perbaikan jiwanya (Anas Ahmad Karzon.

Jurnal At-Tafkir: Volume 13 Nomor 1 Tahun 2020

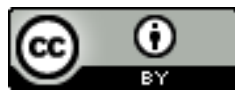

This work is licensed under a Creative Commons Attribution 4.0 International License 


\section{Haji sebagai sarana kecintaan manusia terhadap Tuhan}

Pelaksanaan ibadah haji berbeda dengan ibadah-ibadah lainnya, bila ibadah shalat dan puasa pelaksanaanya lebih banyak mengandalkan fisik, sementara zakat dan infak terkonsentrasi pada harta maka ibadah haji merupakan ibadah membutuhkan fisik, hati dan financial, ibadah haji diwajibkan hanya sekali seumur hidup dan bagi yang mampu, dilaksnakan pada tempat yang tertentu yaitu di tanah haram (Makkah), dilakukan pada bulan yang tertentu pula yaitu bulan haji karena dalam perintah haji terdapat mamfaat sebagaimana Allah berfirman pada surat al-Hajj: 27 sebagai berikut:

$$
\text { "ليشهدوا منافع لهم ويذكروا اسم الله في أيام معلومات على ما رزقهم من هيمة الأنعام فكلوا }
$$

Artinya: Agar mereka menyaksikan berbagai mamfaat untuk mereka dan agar mereka menyebut nama Allah pada beberapa hari yang telah ditentukan atas rezeki yang telah diberikan Dia kepada mereka berupa hewan ternak, maka makanlah sebagian darinya berikanlah untuk dimakan orang-orang yang sengsara dan fakir. (al-Hajj: 27).

al-Nadwi memberikan keterangan terhadap mamfaat haji pada diri manusia yaitu, ibadah haji mampu membangkitkan kerinduan, kecintaan dan kedekatan kepada Allah Ta'ala, karena didalamnya mengandung elemen kasih sayang dan kelembutan yang tertanam dalam sifat manusia, haji merupakan rumah hiburan dan ziarah untuk membentuk kelembutan hati dan kasih sayang, ibadah haji juga disebut ibadah yang memilki tantangan besar disamping ia telah mengorbankan waktu yang lama juga mengeluarkan materi yang banyak dan membutuhkan fisik yang kuat.

Lebih lanjut al-Nadwi mendiskribsikan bahwa ibadah haji sebagai dakwah dalam hal beriman kepada yang ghaib sekaligus mengikuti perintah semata karena Allah Ta'ala ia merupakan tapak tilas kisah Nabi Ibrahim As dan sekaligus mematenkan kehusususan dan peninggalannya, dimana didalam syariat haji tersimpan misi dakwah dan pendidikan, disamping itu haji merupakan sinyal ketaatan dan simbul sukarela bagi yang melakukannya dengan ikhlas, ibadah haji Jurnal At-Tafkir: Volume 13 Nomor 1 Tahun 2020

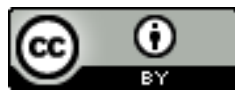

This work is licensed under a Creative Commons Attribution 4.0 International License 
juga berfungsi sebagai penyagga tiang kemanusiaan dalam membangun peradaban dan catatatan sejarah manusia, dimana Islam datang melalui Muhammad dan dijadikannya ka'bah sebagai kiblat ummat yang menjadi sentral hidayah dan petunjuk Tuhan sekaligus sebagai sinyal spiritual yang mengisi asupan emosional kasih sayang yang terdapat disekeliling Ka'bah dan mampu menyalakan sinar hati sehingga mampu mempertemukan dengan risalah agama (Abu Hasan al-nadwi, tt).

Ibadah-ibadah sunnah (nawā̄fil) membaca al-Qur'an, zikir, doa dan jihad.

Salah satu pintu kebaikan dan sarana untuk mencapai ketaatan, nikmat iman dan kemulian dari Allah adalah dengan mengerjakan amalan-amalan sunnah (nawaājil) karena dengan melaksanakan perintah sunnah seorang hamba ia telah berupaya untuk mendekatkan dirinya kepada Tuhan dan dia telah berusaha untuk menyucikan jiwannya dan menghidupkan hatinya dengan keimanan. Jika seorang hamba ingin mendekatkan diri kepada Allah Ta'ala dan memberikan nutrisi bagi jiwanya maka hendaklah bersegera melakukan ibadah-ibadah sunnah sebanyak mungkin dan ia harus berjihad melawan hawa nafsu yang menghalanginya untuk melaksanakan ibadah tersebut, bila ia mampu melawan hawa nafsu niscaya derajat jiwanya akan meningkat sehingga ia mampu merasakan manisnya iman dalam dirinya dan mampu merealisasikan dalam kesehariannya dengan sifat yan lembut dan tenang dalam menghadapi segala bentuk cobaan.

Dalam hal amalan sunnah peneliti menghadirkan tiga amalan sunnah yang besar dan berdampak dalam jiwa manusia yaitu sesuai dengan temuan dalam buku "akidah, ibadah dan suluk" karangan al-Nadwi.

Pertama, membaca al-Qur'an dan mentadabburkanya

al-Nadwi berpendapat bahwa dalam membaca al-Qur'an hendaknya berharap ada tiga harapan yang dapat diambil dari mentadabburkannnya yaitu; penarikan (al-Ajru), rahasia atau penutupan (al-Sitru) dan menghimpun (alhasyru), adapun yang dimaksud dengan dengan al-Ajru yaitu menarik atau Jurnal At-Tafkir: Volume 13 Nomor 1 Tahun 2020

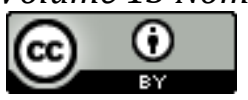

This work is licensed under a Creative Commons Attribution 4.0 International License 
mengambil segala mamfaat dari al-Qur'an dan sibuk dengan mentadabburkannya kemudian berdakwah dengan al-Qur'an dan yang dimaksud dengan al-Sitru adalah segala hal yang tidak dapat diuaraikan melalui akal pikiran manusia dirujuk kepada al-Qur'an melalui penafsirannya, sedangkan al-Hasyru adalah segala bentuk khidmat kepada al-Qur'an dan orang-orang yang mentadabburkannya.

Lebih lanjut al-Nadwi menjelaskan fadhilah terbesar dalam membaca alQur'an adalah hati manusia terasa aman, tentram dan puas dengan muatanmuatan al-qur'an, merasakan betapa besar mu'jizat al-Qur'an, vitalitasnya dan keabadiannya, kemudian menjadi petunjuk dan suluh bagi manusia di setiap zaman dan tempat di dunia ini (Abu Hasan al-Nadwi, 1991) dengan membaca alQur'an secara terus menerus dapat menjaga dan mendidik jiwa dalam berbagai hal, dengan kata lain al-Qur'an dapat memberitahukan kepada manusia terhadap apa yang dinginkan dan memberi efek dari setiap arti yang terkandung didalamnya dalam hal ini tazkiyah al-Nafs. Menurut said Hawwa membaca alQur'an dapat menyinari dan mengingatkan hati manusia karena membaca alQur'an bisa menyempurnakan amalan-amalan wajibah lainnya Kedua berzikir dan berdoa kepada Allah Swt

Berbagai keutamaan berzikir dan berdoa terdapat dalam al-Qur'an dan hadis Rasulullah dan juga para ulama-ulama terdahulu banyak membahas tentang keutamaan zikir dan doa seperti Ibnu Qayyim mengatakan bahwa doa merupakan obat yang paling mujarab dan banyak mamfaat dalam kejiwaan dan kehidupan manusia, karena doa dapat mencegah, meringankan dan menghilangkan musibah yang datang (Ibnu Qayyim, 2017). Dalam al-Qur'an banyak teradapat ayat-ayat yang berkenaan dengan perintah untuk bedoa diantaranya yang terdapat pada surat al-Baqarah: 186 dimana Allah Ta'ala menghibau kepada hambanNya apabila ada yang bertanya tentang Allah maka jawablah bahwasanya aku dekat, Allah mengabulkan segala permintaan orangorang yang berdoa jika ia memohon kepada Allah. Pada surat al-Mu'min: 60. Allah juga memerintahkan hambanya untuk selalu berdoa karena Allah akan

Jurnal At-Tafkir: Volume 13 Nomor 1 Tahun 2020

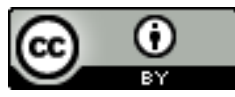

This work is licensed under a Creative Commons Attribution 4.0 International License 
mengabulkannya. Sementara menurut hadis doa dianggap sebagai senjata bagi orang-orang mukmin (الدعاء صلاح المؤمنين).

Ketiga berjihad di jalan Allah

Terjadi kekeliruan terhadap pemahaman jihad sekarang ini, sebagian umat Islam menganggap jihad hanya semata-mata untuk berperang melawan kafir atau mengerjakan amar ma'ruf nahi munkar, sebaliknya orang-orang sufi menganggap bahwa metode penyucian jiwa diharuskan bermeditasi melaui pengasingan diri atau menjauhkan diri dari masyarakat, mereka harus sibuk dengan dirinya sendiri tanpa menghiraukan orang lain, dan mengira bahwa orang muslim harus hijrah dari dunia dan segala isinya dan memasrahkan diri kepada agamanya dan mengosongkan hatinya (takhalli) sebagai terapi dan mengendalikan jiwany, pendapat seperti ini dianggap keliru dan menyimpang karena telah mengaburkan prinsip-prinsip penyucian jiwa yang benar sebagaimana yang terdapat dalam ajaran Islam.

al-Nadwi mendekripsikan jihad merupakan seuatu usaha yang dikerahkan dengan segala upaya dengan tujuannya adalah untuk mendapat kemenangan yang besar. Adapun tujuan tersebesar dalam hidup seorang muslim adalah taat kepada perintah Allah dan mampu meraih ridha Allah serta tunduk pada kepastian hukumNya. Untuk mendapatkan tujuan dan kemenangan yang besar dituntut untuk bersungguh-sungguh dan membutuhkan perjuangan yang panjang dengan melawan segala bentuk rintangan apakah dalam bentuk kepercayaan, pendidikan, akhlak, tujuan hidup, kecenderungan hawa nafsu dalam jiwa, apabila rintangan itu terdapat dalam diri seorang muslim maka ia harus melawannya atau berjihad dengan segala upaya, dalam istilah falsafat disebut dengan mujahadah.

Adapun tingkatan jihad menurut al-Nadwi ada empat yaitu; jihad melawan nafsu, jihad melawan bujukan syaitan, jihad melawan kafir dan jihad melawan orang munafik, dua hal supaya jihad berperan dalam jiwa seseorang yaitu ikhlas kepada Allah dalam berjihad dan mempraktekkan semua yang diperintahkan Allah dan menyeru kepada orang lain, menurut Anas Ahmad

Jurnal At-Tafkir: Volume 13 Nomor 1 Tahun 2020

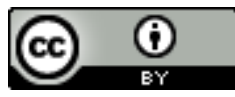

This work is licensed under a Creative Commons Attribution 4.0 International License 
Karzon jihad yang berpengaruh pada jiwa yaitu jihad membebaskan dari cinta kepada kehidupan duniawi dan ketergantungan kepadanya, jihad menguji jiwa serta melatih kesabaran dan pengorbannya dan jihad dijadikan sebagai harga diri dan kekuatan jiwa.

Oleh karena itu jihad yang berkaitan dengan tazkiyah al-Nafs adalah jihad pada tingkat pertama yaitu jihad yang paling besar adalah jihad melawan dirinya sendiri dari insting jahat yang mengarah kepada perbuatan jahat, dan bermujadah terhadap pelaksanaan ibadah..

\section{Fiqih al-Bathin sebagai bentuk tazkiyah al-Nafs}

Setelah mengisi dengan melakukan ibadah mahdhah dan berbagai ibadah sunnah (al-Nawafil) yang diperintahkan Allah Ta'ala maka metode tazkiyah al-Nafs selanjutnya akan membentuk sifat-sifat batiniyah yang baik dan terbentuk akhlak kejiwaan yang terpuji bagi manusia sehingga terbentuklah tazkiyah seseorang dalam jiwanya secara sempurna. Dalam kaitan ini al-Nadwi menggaris bawahi bahwa amaliah bathiniyah atau sikap batin mengiringi amaliyah dhahiriah selanjutnya amaliyah tersebut dijadikan sebagai treatmen terhadap penyakitpenyakit jiwa seperti penyakit hasad, kikir, takabbur, egois, membanggakan diri, ingin dipuji orang, munafiq.

\section{Iman sebagai fiqih batin dan pengontrol jiwa manusia}

Berbica tentang batin al-Nadwi berpendapat sebagaimana terdapat dalam kitabnya Maza khasiral Alam bahwa iman bagaikan institusi moral dan lembaga pendidikan jiwa yang mengajarkan nilai-nilai dan kekuatan jiwa yang kokoh dan juga memberikan latihan intropeksi diri dan bersikap adil pada diri sendiri, iman diakui sebagai faktor pengendali paling kuat terhadap tindakan penyelewengan moral, prilaku dan dekadensi kemanusian (Abu Hasan al-Nadwi, 1994) dan dengan imanlah manusia bisa selamat dari perangai-perangan hayawaniyah yang kadang-kadang mendominasi jiwa manusia ketika manusia terlepas dari sifat insaniyahnya. Tanpa diawasi pun iman mampu merobah identitas hawa nafsu Jurnal At-Tafkir: Volume 13 Nomor 1 Tahun 2020

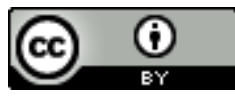

This work is licensed under a Creative Commons Attribution 4.0 International License 
yang menyeru untuk kejahatan (al-Nafsu al-Lawwamah), kadang-kadang jiwa membantu untuk mendatangkan penderitaan dalam batin, jiwa menciptakan khayalan-khayalan menakutkan, untuk itu manusia dalam menyehatkan batinnya menurut al-Nadwi dibutuhkan keteguhan hati dalam menghadapi godaan hawa nafsu dan kebesaran jiwa.

\section{Amaliah batiniah sebagai pembentukan tazkiyah al-Nafs}

Secara umum al-Nadwi mengambarkan 22 sifat yang harus selalu dibangun dalam pribadi manusia untuk membentuk tazkiyah al-Nafs yaitu: ikhlas, taubat, sabar dan pemaaf, bertakarrub kepada Allah, bertaqwa sesuai dengan perkataan dan perbuatan, yakin dan tawakkal, istiqamah, berpegang teguh kepada al-Qur'an dan sunnah rasul, cinta kepada Allah dan rasul, saling membantu dalam berbuat baik dan taqwa, persatuan islamiyah, menempati janji, saling memperbaiki antara manusia dan amalan-amalan yang bermamfaat, berlemah lembut dan tawadhu', mengikuti contoh rasul, takut kepada Allah dan berharap kepadanya, zuhud terhadap duniawiyah, tidak mementingkan diri sendiri, larangan untuk merusak, memperbagus akhlak dan memilki jiwa yang bersih, saling bersahabat sesama manusia dan memberi hak kepada muslim lainnya.

Meskipun amalan-amalan hati ini tidak dijelaskan secara mendetail, hanya menyebut ayat-ayatnya saja namun, peneliti melihat inilah skema tazkiyah al-Nafs atau model fiqih batin yang digambarkan al-Nadwi dan dikelompokkan amalan tersebut menjadi tiga bagian yang menghubungkan manusia dengan Allah, manusia dengan manusia dan hubungan antara manusia dengan Allah dan dengan manusia. Adapun sifat-sifat yang dimaksud al-Nadwi sebagai berkut

1. Hubungan dengan Allah (hablum minallah) seperti: Taubah nasuha, bermurakabah kepada Allah, ketakwaan sesuai dengan perkataan dan perbuatan, yakin dan tawakkal, istiqamah, berpegang teguh pada al-Qur'an dan Hadis, takut dan berharap hanya kepada Allah, zuhud di dunia.

Jurnal At-Tafkir: Volume 13 Nomor 1 Tahun 2020

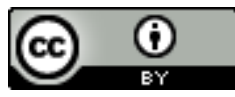

This work is licensed under a Creative Commons Attribution 4.0 International License 
2. Hubungan dengan manusia seperti, saling tolong menolong dalam kebaikan, persaudaraan islamiah, menunaikan amanah, saling memperbaiki dalam kesalahan sesama manusia dan beramal dengan amalan yang bermamfaat, bersikap lemah lembut dan tawadhu', mendahulukan orang lain terhadap dirinya, bersahabat sesama manusia dan memberikan hak sesama muslim.

3. Hubungan antara Allah dan manusia seperti; ikhlas, sabar dan pemaaf, cinta kepada Allah dan Rasul, mengikuti uswah Rasul, mengharamkan kesombongan dan kerusakan, berakhlak yang baik dan mampu mengendalikan dirinya.

Tazkiyah al-Nafs bila dikoneksikan dengan pendidikan Islam ia akan menjadi roh yang sangat penting untuk membentuk akhlak yang mulia bagi peserta didik. Hal ini selaras dengan kesepakatan dan pemahaman para tokoh pendidikan Islam yang dirumuskan pada konferensi pendidikan Islam sedunia yang ke-2 pada tahun 1980 di Islam Islam Abad bahwa pendidikan Islam harus bertujuan untuk mencapai keseimbangan pertumbuhan personalitas manusia secara menyeluruh dengan cara melatih jiwa, akal, perasaan dan fisik manusia. oleh sebab itu pendidikan diarahkan untuk mengembangkan manusia pada seluruh aspeknya: spiritual, intelektual, daya imaginasi, fisik, keilmuan dan bahasa, baik secara individual maupun kelompok, serta mendororong seluruh aspek tersebut untuk mencapai kebaikan dan kesempurnaan dan pada akhirnya pendidikan bertujuan untuk merealisasikan pengabdian manusia kepada Allah Taala, baik pada tingkat individual, kemasyarakatan dan kemanusian (Abuddin Nata, 2016).

Dalam kaitannya dengan pendidikan Islam terdapat beberapa istilah yang dikemukakan oleh para ahli yaitu al-Ta'lim, al-Tarbiyah, al-Tadris, al-Ta'dib, alTahzib, dilihat dari maknanya secara harfiah berarti pendidikan, namun bila ditelaah secara epistimologi makna dari kata-kata tersebut menjadi perdebatan diantara para ahli, seperti kata tarbiyah yang dipopelerkan oleh 'Athiah alAbrasyi, ia lebih suka menggunakan kalimat tarbiyah untuk memaknai pendidikan, karena secara prakteknya kata ini mencakup seluruh pendidikan

Jurnal At-Tafkir: Volume 13 Nomor 1 Tahun 2020

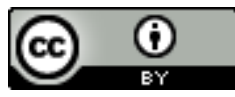

This work is licensed under a Creative Commons Attribution 4.0 International License 
yaitu suatu upaya mempersiapkan anak didik untuk mencapai kesempurnaan, mencapai kebahagiaan, cinta tanah air, memperkuat fisik, menyempurnakan Akhlak, menumbuhkan kreatifitas pada anak. Sementara ta'lim adalah bagian daripada tarbiyah yang mencakup hanya pada ranah kognitif, berbeda yang dikemukan oleh Abdul fatah Jalal dikutip oleh Muhammad Muchlis mengatakan bahwa istilah ta'lim lebih luas daripada tarbiyah karena kata itu muncul pada masa sadrul Islam dan istilah ini digunakan rasulullah dalam mengajarkan bacaan al-Qur'an kepada kaum muslimin, pengajarannya tidak terbatas pada upaya agar mereka dapat membaca, akan tetapi lebih daripada hal tersebut yakni membaca sekaligus menghayati dan memahami. (Muhammad Muchlis Solichin, 2009).

Berbeda dengan Nuqaib al-Attas menggunakan kalimat al-ta'dib dalam menjelaskan pendidikan, Nuqaib lebih suka menggunakan Istilah al-Ta'dib ketimbang al-tarbiyah atau lainnya karena menurutnya al-Tarbiyah terlalu luas arti dan jangkauannya, kalimat tarbiyah tidak hanya berbicara pada dataran manusia saja melainkan juga menjaga alam semesta, menurutnya alam semesta tidak bisa didiik karena benda alam semesta tidak memilki persyaratan potensial seperti akal, panca indra, hati nurani, insting dan fitrah, sedangkan kata al-Ta'dib menurut Nuqaib al-ta'dib merupakan kalimat yang menjadikan seseorang sebagai pengenalan dan pengakuan kepada Tuhan secara berangsur tertanam pada diri manusia, kalimat ini dianggap kalimat yang sangat tepat untuk dijadikan pendidikan sebagai sarana transformasi nilai-nilai akhlak yang bersumber pada ajaran agama kedalam diri manusia, serta menjadikannya sebagai proses Islamisasi ilmu pengetahuan (Abudin Nata, 2016).

Lain halnya dengan kalangan sufis mereka lebih suka menggunakan kalimat Riyadhah untuk memahami pendidikan karena pendidikan menurut mereka harus mendidik jiwa anak dengan akhlak yang mulia, mereka mengartikan riyadhah sebagai latihan spiritual rohaniah dengan cara khalwat dan uzlah diiringi dengan perasaan batin dengan tujuan mampu menahan segala bentuk ghirah kedunawiyah. Menurut Abuddin Nata penggunaan kalimat

Jurnal At-Tafkir: Volume 13 Nomor 1 Tahun 2020

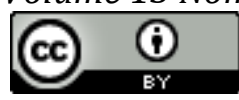

This work is licensed under a Creative Commons Attribution 4.0 International License 
artarbiyah untuk menjelaskan pendidikan oleh para ahli lebih banyak dibandingkan istilah-istilah yang disebutkan diatas seperti Ibnu taimiyah, Ibnu Sina, Muhammad Qutub, Atiyah al-Abrasyi, Ahmad Tsalabi dan lainnya.

Abu Hasan sendiri dalam beberapa komentarnya lebih suka menggunakan al-Tarbiyah seperti dalam karanganya al-tarbiyah al-Islamiyah al-Hurrah, meskipun al-Nadwi tidak menceritakan secara terperinci terhadap pemaknaan dari istilahistilah terhadap pendidikan, namun bila dilihat dari kandungan kitab yang dikarang beliau isinya menggambarkan pemaknaan tarbiyah, karena menurutnya pendidikan harus mengacu pada nilai juga mengakomudir kemoderenan dan bila dilihat lebih lanjut terhadap kurikulum yang digambarkan al-Nadwi mencakup akidah Islamiyah, Tsaqafah Islamiyah, Sain dan teknologi, sejarah Islam, keterampilan, dakwah dan kepemimpinan serta olah raga (Abu Hasan al-Nadwi, 1977).

Oleh karena itu dilihat dari istilah-istilah diatas terdapat sinergisitas antara istilah-istilah dalam meletakkan penanaman sikap dan akhlak karimah melaui penyuscian jiwa (tazkiyah al-Nafs) dan bisa diintegrasikan dalam dunia pendidikan sekarang ini yang sedang dilanda krisis moral.

Bab IV Penutup.

Dari uraian pembahasan tentang pemikiran tazkiyah al-Nafs menurut pandangan Abu Hasan al-Nadwi dapat disimpulkan bahwa tazkiyah al-Nafs dinamakan dengan figh al-batin atau al-Ihsan yang berfungsi sebagai pengobat hati dan sebagai pengawalan terhadap hawa nafsu yang ada pada diri manusia.

Adpun tipologi tazkiyah al-Nafs menurut al-Nadwi ada dua, pertama ibada-ibadah wajibah dan ibadah-ibadah sunnah (figh dhahir) disebut juga dengan ibadah haia't dan ibadah-ibadah batin (fiqh batin). Pada prakteknya kedua ibadah ini bekerjasama saling mengisi satu sama lain dalam proses tazkiyah al-Nafs sehingga melahirkan akhlak al-karimah dalam diri manusia, atau dalam istilah tasawuf disebut mengosongkan diri dari perbuatan jahat (takhalli) kemudian

Jurnal At-Tafkir: Volume 13 Nomor 1 Tahun 2020

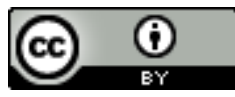

This work is licensed under a Creative Commons Attribution 4.0 International License 
mengisi dengan amalan shalih (tahalli) dan pada akirnya melahirkan seseorang berakhlak karimah seperti akhlak rasul (tajalli).

Sebagai saran dalam penulisan artikel ini sebagai berikut

1. metode tazkiyah model Abu Hasan al-Nadwi hendaknya dilakukan pada setiap pribadi muslim khususnya para pendidik berupaya untuk mengintegrasikan dalam praktek pembelajaran supaya peserta didik menjadi seorang yang berakhlak yang mulia.

2. berkaca pada model tazkiyah al-Nafs fersi Abu Hasan al-Nadwi sangat simple dan mudah untuk diterpkan kapanpun dan dimanapun.

3. Tulisan ini perlu dikembangkan lebih lanjut dan dapat diinterkoneksikan dengan berbagai disiplin ilmu agama lainnya khususnya dengan pendidikan.

\section{DAFTAR PUSTAKA}

Abu Hasan al-Nadwi, (tt), al-Arkan al-Arba', Dar al-kutub al-Islamiyah. Abu Hasan al-Nadwi, (1966), Rabbaniyah La Ruhbaniyah, Bairut: Dar al-Fatah

Abu Hasan al-Nadwi, (1968) al-Shira' Baina al-Fikrah al-Islamiyyah wa al-Fikrah alGharbiyyah, Libanon: Dar al-Nadwi Li Tauzi' Cet. 2

Abu Hasan al-Nadwi, (1983), al-Akidah Wal Ibadah Wassuluk Fi Zau'il Kitab Wassunnah Wa Sirah Nabawiyah Lucknow, India: al-Majma' al-Ilmi.

Abu Hasan al-Nadwi, (1987), Ilal Islam Min Jadid, Lucknow, India: al-Majma' alIslamiy al-Ilmiy.

Abu Hasan al-Nadwi, (1991), Tamallat fil Qur'an al-karim, Damaskus: Darul Qalam.

Abu Hasan al-Nadwi, (1994), Maza Khasiral 'Alam bi Inhithat al-Muslimin, Lucknow, India: al-Majma' al-Islami al-'Ilmi.

Abu Hasan al-Nadwi, (1977), al-Tarbiyah al-Islamiyyah al-Hurrah, Bairut: Muassasah al-Risalah.

Abdul Mun'im Usman, (2010) Abu Hasan wa Fikratuhu al-Tarbawi (Khurtum: Hai'ah al-'Amal al-Fikriyyah

Abuddin Nata, (2016), Ilmu Pendidikan Islam, Jakarta: Prenada Media Group, Cet. 3 .

Ahmad Warson, (2002), Kamus al-Munawwir, Surabaya: Pustaka Progressif, cet. 25

al-Munjid, (1986), kamus al-Munjid, Bairut: Darul Masyriq.

Jurnal At-Tafkir: Volume 13 Nomor 1 Tahun 2020

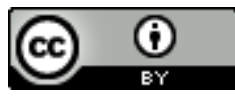

This work is licensed under a Creative Commons Attribution 4.0 International License 
Anas Ahmad Karzon, (2016), Tazkiyah al-Nafs, Terj. Emiel Threeska, Jakarta: Akbar Media.

Azhari setiawan, (2017), Syed Abul Hasan Ali Hasani al-Nadwi Tentang Keruntuhan Peradaban, Pandangan Hidup dan Pendidikan Islam, Tasfiyah: Jurnal Pendidikan Islam, Vol. 1, No. 2 Agustus.

Azyumardi Azra, (2001), Pendidikan Akhlak dan Budi Pekerti; Membangun kembali Anak Bangsa, Jurnal Mimbar Pendidikan No. I/XX

Ibnu Kasir, (1998), Tafsir al-Qur'an al-'Azim, Bairut: Darul Kutub al-Ilmiyah

Ibnu Taimiyah, (1994), Tazkiyah al-Nafs, Tahkik, Muhammad Ibnu Sa'id alQahthani, Riyadh: Darul Muslimah.

Ibnu Qayyim al-Jauziyah, (2017), Terapi Penyakit Hati, terj. Salim Bazemool, Solo Pustaka Mantiq.

Mada Wijaya, ( 2016), Pemikiran Pendidikan al-Nadwi dalam Kitab Ash-Shira' Baina al-Fikrah al-Islamiyyah wal Firah al-Islamiyyah, Rayyah: Jurnal Pendidikan Islam, vol. 1 No. 1

M. Abduh al-Mannar dkk, (2018), Konsep Pendidikan Islam al-Nadwi Dalam Menangkal Liberarisasi, Seminar nasional.

Muhammad Ijtiba' al-Nadwi, (2001), Abu Hasan Ali al-Nadwi al-Da'iyah al-Hakim wa al-Murabbiy al-Jalil, (Damaskus: Darul Qalam.

Masyuri, (2012), Prinsip-Prinsip Tazkiyah al-Nafs dalam Islam dan Hubungannya dengan Kesehatan Mental, Jurnal Pendidikan Islam Vol. 1, 37, No. 2 JuliDesember.

Muhammad Habib Fathuddin, Fachrur Razi Amir, (2016), Konsep Tazkiyah alNafs Menurut Ibnu al-Qayyim al-Jauziyah dalam Kitab Madarijul Salikin Serta Implikasinya Terhadap Pendidikan, Jurnal Ta'dibi, ISSN. 2442-2994, Vol. 5, no. 2 Oktober.

Muhammad Muchlis Solichin, (2009), Tazkiyah al-Nafs Sebagai Ruh Rekontruksi Pendidikan Islam, Jurnal Tadris, Vol. 4. Nomor 1.

Sayed Iqbal Zaheer, (2005), Aman of Hope Through a Century of Turmoil, (Banglore India: Iqra' Welfare Trust.

Sori Monang, (2018), Recontruction of Western Civilization Viewed by Sayyid Abu Hasan Ali al-Hasani al-Nadwi, Budapest International Research and Critic Institute-Journal (BIRC)-Journal, vol. 1 No. 2

Yusuf Qaradhawi, (2001) Abu Hasan al-Nadwi Kama 'Araftuhu, Damaskus: Darul Qalam.

Jurnal At-Tafkir: Volume 13 Nomor 1 Tahun 2020

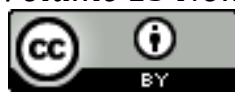

This work is licensed under a Creative Commons Attribution 4.0 International License 